УДК 625.1(47)-055.2(091)(045)

\title{
B.A. Сердюк
}

\section{ЖЕНСКИЙ ТРУД НА ЖЕЛЕЗНЫХ ДОРОГАХ РОССИЙСКОЙ ИМПЕРИИ: ИСТОРИОГРАФИЧЕСКИЙ ОБЗОР}

Статья посвящена общему историографическому обзору отечественной и зарубежной литературы по исследованию проблемы использования женского труда на железных дорогах. Предметом исследования являются публикации дореволюционных, советских и современных исследователей о роли и значении женского труда в развитии железнодорожной отрасли Российской империи в XIX — начале XX в. Обобщая наработки исследователей, автор предпринимает попытку ответить на вопрос, как оценивалась роль женского труда в железнодорожной деятельности в дореволюционный и советский периоды, а также после распада СССР. В статье сделан вывод о том, что литература постсоветского периода существенно расширила рамки изучения проблемы, однако до сих пор опирается на историографию советского периода.

Ключевые слова: историография, женщина, женский труд, железные дороги, железнодорожная служба, Российская империя.

DOI: $10.35634 / 2412-9534-2021-31-1-22-33$

Почти два столетия отделяют нас от даты появления первой в России железной дороги общего пользования. С тех пор железнодорожный транспорт стал основой социально-экономического роста страны, а его стабильное функционирование зависит от слаженной работы сотен тысяч работников, в т. ч. женщин. Представить современные железнодорожные пути сообщения без них уже невозможно и в России, и за рубежом. Цифры говорят сами за себя: в 2017 г. совокупная доля женщин среди работников ОАО «Российские железные дороги» составляла 31,3 \% [39, с. 144]. При этом женщины занимали более $50 \%$ мест руководителей и специалистов компании в период с 2007 по 2017 г. Но то в настоящем, а какова была ситуация в прошлом?

В XIX в. служба на железных дорогах прочно ассоциировалась с трудом многих поколений мужчин, считаясь сугубо мужской сферой деятельности. Такая точка зрения укрепилась и стала доминирующей в отечественной историографии. И хотя в настоящее время наука переживает процессы переосмысления традиционных направлений исследований (в которых при изучении политики, экономики и культуры женщинам зачастую отводилось место общего фона, существование которого всем очевидно, но которое не вписано в историческое полотно), в море исторической и научнопублицистической литературы уделяется поразительно мало внимания женскому вкладу в деятельность железных дорог. Автор настоящей статьи предпринимает попытку историографического осмысления существующего массива источников и литературы, напрямую или косвенно затрагивающих тему женского труда на железных дорогах Российской империи. Конечной целью является оказание помощи исследователям, стремящимся «встроить» женщин в традиционную схему исторического повествования.

Истоки «женской темы» в российской историографии лежат в $1850-\mathbf{x} г г$., изучая культуру и географию русской народности, этнографы попутно открыли для себя «женщину низших русских классов, забытую чуть не с вечных времен» [2, с. 40]. По словам писателя А. В. Амфитеатрова, «сразу всплыла со всех углов русская женская жизнь, таившаяся под спудом, и всюду оказалась она одинаково полной громкого протеста, одинаково ищущая выхода из мрака к свету, одинаково враждебная насилиям старины и алчущая свободы, знания и самостоятельной деятельности» [2, с. 41]. В 1858 г. в столичной периодической печати появился ряд статей о женском труде, вызвав оживлённую полемику [22].

В разгоревшейся общенациональной дискуссии конца 1850-х — начала 1860-х гг. женский труд представал в качестве одного из аспектов так наз. женского вопроса, включавшего в себя не только требование общественного равноправия (достижение которого представлялось невозможным без профессиональной самореализации женщин), но и проблемы взаимоотношений мужчин и женщин, семьи и брака, охраны и защиты материнства. Отмена крепостного права в 1861 г. способствовала дальнейшему расширению социальных ролей женщин, заявивших о своём праве на свободный труд. Среди прочего современники обратились к теме женского труда на железнодорожном транспорте. 
В 1860-1880-е гг. отдельные периодические издания впервые стали приводить доводы в пользу или против использования женского труда на разных должностях в железнодорожной отрасли [11, с. $190-191 ; 31$ с. $80 ; 63$, с. $278 ; 13$, с. 792-807], ссылаясь не только на мужскую, но и на женскую точки зрения. В целом же дореволюционные издания периода Великих реформ Александра II если и писали о занятости женщин на железных дорогах, то лишь обозначая существовавшие в то время правила их приёма на службу [64, с. 126; 9, с. 75].

Попытки охарактеризовать исследуемый нами вопрос стали предприниматься с 1890-х гг. Небольшие исторические очерки о «служащих женского пола» были включены в работы общего характера $[40$, с. 44-45; 24, с. 30-32; 26, с. 176-177]. Это были первые ретроспективные обзоры службы женщин на железных дорогах России, опирающиеся на изданные в 1860-1890-е гг. ведомственные нормативно-правовые акты.

В 1896 г. о железнодорожной службе женщин высказался инженер путей сообщения И. И. Рихтер, упомянув в своей работе о личностных качествах переездных сторожих и об отношении к женскому труду частных железнодорожных компаний (обществ) [51, с. 92, 149]. В 1900 г., опираясь на статистические данные пенсионной статистики за 1898 г., И. И. Рихтер показал образовательный уровень женщин-служащих, их количество, возраст, семейное положение, а также продемонстрировал отношение к женскому труду на железных дорогах в странах Западной Европы [52, с. 17-29, 73-74]. Аналогичным образом поступила в 1908 г. на I Всероссийском женском съезде докладчица А. А. Глинская, кратко осветив экономическое положение железнодорожниц на разных должностях [15, с. 400-404], a затем доктор И. М. Покровская в периодическом издании «Женский вестник» [45, с. 120-123].

В отличие от большинства названных работ, косвенно затрагивавших исследуемую проблематику, изданный в 1894 г. труд В. Н. Щеголева был специально посвящён службе женщин-телеграфисток [65, с. 42-46]. Автор описал условия службы на железнодорожных телеграфах России в период с 1860 по 1890-е гг., особенности порядка приема женщин-телеграфисток, сравнив их с аналогичным зарубежным опытом.

О железнодорожницах писали, как правило, обезличенно, исключением стала одна из них Ольга Степановна Кнушевицкая. Биография О. С. Кнушевицкой удостоилась на удивление пристального внимания, поскольку в Российской империи её было принято именовать не иначе как «первой железнодорожницей России» [44, с. 7-8; 36, с. $8-9 ; 12$, с. 2 ; 43, с. 2 ; 42, с. 61-63]. Сегодня данный тезис активно тиражируется российскими авторами.

В 1911 г. инженер путей сообщения Н. П. Верховской предпринял целенаправленную попытку всестороннего исследования женского труда на железных дорогах, по собственной воле обратившись за соответствующей информацией в Управление железных дорог России. По всей видимости, это был единственный подобный случай. Сначала Управление железных дорог России благосклонно отнеслось к запросу Н. П. Верховского, но затем инженер натолкнулся на противодействие со стороны министра путей сообщения Н. К. Шаффгаузен-Шенберг-эк-Шауфуса (Н. К. Шауфуса), посчитавшего его действия неправомочными. «Подул ветер с другой стороны, и Управление железных дорог не пожелало продолжения моего исследования», - с сожалением заметил Н. П. Верховской [38, с. 46д]. Не достигнув конечной цели, но подчёркивая, что «женский вопрос на железных дорогах один из серьёзнейших, как в смысле трудовой силы, так и воспитательной» $[10$, с. 97], инженер перечислил должности, доступные женщинам на железнодорожной службе, попытался проанализировать их количественный и качественный состав, охарактеризовал взаимоотношения с мужчинами - коллегами $[10$, c. $93-98]$.

Хронологически последней дореволюционной работой была брошюра 3. И. Лилиной, написанная в 1916 г. с позиций социал-демократического движения и изданная уже в РСФСР. Будущая советская партийная и государственная деятельница описала условия женского труда и размер заработной платы работниц всех основных стран-участниц Первой мировой войны, упомянув и о железнодорожницах [30, с. 17, 26, 42-43, 106].

Несмотря на указанные выше работы, проблема использования женского труда на железных дорогах в дореволюционный период большей частью осталась неизученной, «почти тёмной» [10, с. 96], тогда как её актуальность осознавалась. В частности, А. А. Глинская, обращаясь к слушателям на женском съезде, заметила: «Опускаясь в мягкий диван вагона... мало кто из присутствующих знает, в чьих руках находится охрана и содержание пути, а вместе с тем в чьих руках находится отчасти и жизнь каждого пассажира. Она находится ни больше, ни меньше, как наполовину в руках женщи- 
ны, - одиноко стоящей на переезде, с зелёным флажком и ночью, и днём, и в стужу, и непогоду» [15, с. 400]. Подтверждением слов А. А. Глинской служат цифры: в 1913 г. на 40 дорогах общего пользования Российской империи несли вахту 34403 сторожа и 26223 сторожихи [21, с. 158].

Несмотря на то, что дореволюционные авторы ближе всего подошли к написанию комплексных работ о женском труде на железных дорогах в рамках методологических черт, присущих «женской истории», им так и не удалось это сделать. Тем не менее, благодаря досоветской историографии, современным исследователям доступны отрывочные сведения, характеризующие количественный и качественный состав женщин на железнодорожной службе в Российской империи, уровень их материального достатка и образования, условия труда на различных должностях, отношение к женскому труду со стороны руководства МПС и рядовых служащих.

В советской историографии господствующим была марксистско-ленинская идеология с присущим ей материалистическим пониманием истории. С позиций марксистско-ленинской теории понятие «класс» не коррелировало с гендерной составляющей социальных процессов, главными признавались только отношения экономические и классово антагонистические, поэтому женщины не представляли собой значимой для исследователей социальной группы [66, с. 21]. «Женский вопрос» стал не только вторичен, не значим для процесса социальных изменений, но и, вообще, не существовавшим отдельно от классовых отношений.

Наглядно данную позицию ещё в 1909 г. выразила А. М. Коллонтай, на долгие годы предопределив основные подходы к исследованию женской темы в советской науке: «Женский мир, как и мир мужской, разделён на два лагеря: один по своим целям, стремления и интересам примыкает к классам буржуазным; другой тесно связан с пролетариатом, освободительные стремления которого охватывают также и решение женского вопроса во всей его полноте» [28, с. 29]. Как утверждали впоследствии советские историки, начиная с середины XIX в., по мере пробуждения классового сознания женщина стала приобщаться к революционному движению, превратившись в «верную подругу рабочего» в борьбе за освобождение от капитала, участником боёв и стачек, окончательной целью которых была полная победа трудящихся [19, с. 5-6]. Советская историография была нацелена на восхваление подвигов участниц революционного движения, и именно с этих позиций упоминалось о женском труде на железных дорогах Российской империи. Считалось, что в условиях «победы пролетарской революции» женского вопроса не может существовать по определению, поскольку наступило долгожданное раскрепощение женщин. Впрочем признавалось, что дискриминация женщин во всех её проявлениях была ликвидирована «не сразу, а в процессе длительной, сложной и упорной работы Коммунистической партии и Советского государства» [55, с. 25].

В годы НЭПа интерес к женской проблематике на железнодорожном транспорте по инерции ещё сохранялся у «старых» исследователей $[48$, с. $91-95 ; 41$ с. $35 ; 17$, с. 11]. Для этого периода был характерен дух экспериментаторства. Так, в августе 1923 г. санитарный врач Е. И. Кефели впервые в отечественной историографии осуществил исследование бытовых, семейных, материальных условий труда женщин, работавших на Юго-Западных железных дорогах с помощью анонимного анкетирования [25]. Но уже в 1930-е гг. произошёл «консервативный поворот», вызванный началом коллективизации и индустриализации. Резкое расширение сфер эксплуатации женщин в отраслях, традиционно считавшихся мужскими, происходило под лозунгами «освобождения женщин», являвшихся частью рабочего класса. Как отмечают специалисты [62, с. 71; 7, с. 103], во второй половине 1930-х гг. было провозглашено: «женский вопрос», как неотъемлемая часть общей борьбы рабочего класса за своё освобождение, окончательно решён. Женщины стали символизировать советские достижения, демонстрируя решительный разрыв с «тёмным» прошлым. Косвенным подтверждением этому стало определение «женского вопроса» в толковом словаре Д. Н. Ушакова, изданном в 1935 г. Определение было дано с примечанием, позволяющим понять, что в новых условиях он превратился в анахронизм: «Женский вопрос (дореволюц. и загр.) - вопрос об уравнении женщин в гражданских правах с мужчинами» [57, с. 858]. На железных дорогах СССР зримым воплощением наступившего гендерного равенства считалась 3. П. Троицкая, - первая советская женщина-машинист паровоза, инициатор движения за овладение железнодорожной техникой среди женщин, в 1938 г., назначенная на пост начальника Московско-Окружной железной дороги [47, с. 1; 37]. После публикации агитационных очерков её примеру последовало множество железнодорожниц, освоивших профессии машинистов и помощников машинистов [35, с. 3]. При этом советская действительность обходила стороной тот факт, что в дореволюционной России в 1916 г. женщины также добились права исполнять обязанности помощника паровозного машиниста. 
Не получив в 1930-1950-е гг. статуса самостоятельной темы, интерес к проблеме женского труда на железных дорогах в дореволюционный период стал неизбежно угасать. Наработки дореволюционных авторов оказались невостребованными. При упоминании о женском труде на железных дорогах в Российской империи стали безапелляционно утверждать, что «на транспорте в отношении женщин царил страшный произвол» и «до революции [женский труд] практически не играл никакой роли» [20, с. 3]. Характерная деталь - в 1951 г. в книге штатного историка Октябрьской дороги А. И. Августынюка (в соавторстве с М. Гвоздевым) был параграф «Первые железнодорожницы», начинающийся словами: «С момента постройки [Николаевской] магистрали [т. е. с 1851 г. - B. С.] и вплоть до Первой мировой войны женский труд на дороге, как правило, не применялся» [1, с. 231].

С началом хрущевской «оттепели», на базе частичного отхода от идеологических штампов и введения в научный оборот новых архивных материалов возник повышенный интерес к частной жизни. Появились работы, в которых женщины, работавщие на железнодорожном транспорте в дореволюционный период, вновь предстали как субъект социальных изменений. Вклад женщин в развитие отрасли (преимущественно в региональном масштабе) стали кратко описывать [50, с. 248-249; 32, c. $220 ; 34$, с. $10 ; 5$, с. $215-217 ; 29$, с. $86-88 ; 23$, с. 64$]$, но с традиционными оговорками: «Использование женского труда на железных дорогах России не нашло широкого распространения» [4, с. 29]. При этом советская историография в большинстве случаев делала акцент на предреволюционной ситуации, обходя вниманием, за редким исключением [6, с. 164-169; 56, с. 101-102], вторую половину ХІХ в. С одной стороны, это обусловливалось тем, что железнодорожники (вместе с входящими в их состав женщинами) рассматривались как одна из ведущих сил классовой борьбы пролетариата. Борьба представлялась необходимой в т. ч. потому, что «реакционный самодержавный режим», по словам томского историка И. Т. Белимова, «ставил огромные препоны на пути привлечения женщин в промышленное производство и, особенно, на железнодорожный транспорт... не веря в ум и способности женщин» [5, с. 215-216]. Даже в диссертационных исследованиях мнение одного высокопоставленного чиновника могло выдаваться за действия всей государственной власти. Так, критические слова в отношении женского труда, высказанные в 1870 г. шефом жандармов П. А. Шуваловым, были обобщены следующим образом: «Высшая царская администрация пыталась совсем запретить промышленную работу женщин, поддерживая тот патриархальный уклад жизни, который исключал их производственную деятельность на железных дорогах» [6, с. 164].

Иными словами, условия женского труда на железных дорогах в трудах советских историков представали фоном, демонстрировавшим глубину экономического и политического кризиса общественного строя Российской империи в начале XX в., предопределившим начало революции сначала в 1905 г., а затем в 1917 г. С другой стороны, историки пользовались доступными им статистическими материалами, количество и качество которых возросло в результате перехода большинства магистралей в казённую собственность в конце 1890-х гг.

С середины 1960-х гг. в советской историографии наметилось медленное смещение объекта изучения с истории абстракций (класс, социальный слой) на историю людей, имеющих пол и свои интересы. На основе аккумуляции дореволюционных статистических данных были опубликованы короткие конкретно-исторические исследования, проанализировавшие динамику половозрастного состава рабочих и служащих железнодорожного транспорта конца XIX - начала XX в., производственный стаж женщин, условия их труда и уровень заработной платы, вопросы охраны материнства на примере некоторых железных дорог $[8$, с. $109 ; 4$, с. 52 ; 3, с. 29-30; 27, с. 126; 16, с. 97-98; 33, с. 101; 58 , с. $123-124,127,139,196]$. В сравнении с зарубежными историками, приступившими с 1980-х гг. к исследованиям женской тематики в рамках «гендерной истории», их советские коллеги (как и дореволюционные) придерживались описательного подхода.

С распадом СССР в отечественной науке стал наблюдаться рост популярности гендерной проблематики в связи с выходом в европейское пространство. Если раньше авторы только описывали с большей или меньшей степенью трагизма положение женщин и формы их борьбы за эмансипацию вплоть до революционных дней 1917 г., то теперь они старались ответить на вопросы, связанные с женской повседневностью, женским социальным поведением, пытались разобраться в причинах, которые (возникнув ещё в доклассовом обществе) поставили представительниц слабого пола в зависимость от сильного [49, с. 19]. Предметом исследований стал не просто поиск места женщины в историческом процессе, но её влияние на социальные, культурные, политические и экономические сферы жизнедеятельности общества, особенности существовавшей гендерной иерархии. Преодолев старые 
представления о том, что равенство и свободу женщинам России дала именно советская власть, догмы о бесправии женщин в дореволюционную эпоху сегодня подвергнуты сомнению.

Тем не менее для значительной части историографии железных дорог определяющее значение до сих пор имеют исследования советского времени, дополняемые отрывочными сведениями дореволюционной поры. Отсюда наблюдается своего рода преемственность в интересующей нас проблематике: как и в советский период, трудовая деятельность служивших на железных дорогах женщин описана в хронологических рамках конца XIX — начала XX в. [46, с. 190-194; 67, с. 30] и, прежде всего, в связи с участием железнодорожников в революционном движении. А эпоха становления и первоначального развития железнодорожного транспорта, когда во многом определялось будущее отрасли, по-прежнему остаётся вне поля зрения исследователей. Современные авторы во многом оперируют теми же данными, что и советские, а потому практически не происходит приращения исторического знания по исследуемому вопросу. Введение новых источников в научный оборот осуществляется значительно медленнее, чем на Западе. Исключение - небольшая статья иркутского историка А. В. Хобта, вышедшая в 2016 г. [59, с. 551-556]. Исследователь не просто перечислил должности, доступные женщинам на железнодорожном транспорте в Российской империи, но и предпринял попытку выявить их положительные и отрицательные деловые качества, проанализировал характер взаимоотношений с сослуживцами. Вместе с тем при обобщениях автор пользовался в основном данными по Транссибирской магистрали, не рассматривая период до 1890-х гг. Некоторые из суждений А. В. Хобта нам видятся спорными и необоснованными, как, например, рисуемый «коллективный портрет» железнодорожницы: «Девушка-женщина, поступая на службу, отчётливо понимала, что она существо нежное и слабое, и требовала от окружавших её мужчин исключительно джентельменского отношения. Служебные дела, естественно, “сваливались” на сослуживцев» [59, с. 551-552]. Учитывая имеющиеся в нашем распоряжении материалы, мы не можем согласиться с подобным обобщением.

Отличительной чертой современной российской историографии является стойкий интерес к биографии О. С. Кнушевицкой $[14$, с. $121 ; 18$, с. 6-7; 54, пол. 6; 61, пол. 7], поступившей на железнодорожную службу в 1863 г. В то время как в исторической науке в 2009 г. было высказано мнение о «недоступности для учёных вопроса о начале использования женского труда на железнодорожном транспорте» [60, с. 18] (очевидно, в силу недостаточного количества источников), авторы научнопопулярных трудов рассыпаются в комплиментах «первой женщине на железнодорожной службе России». Биография О. С. Кнушевицкой - яркий пример тиражирования ошибок вследствие игнорирования первоисточников авторами научно-популярных изданий (см. об этом: [53, с. 142-160]). Опасность заключается в том, что фактологическая ошибка, размноженная в трудах публицистического характера, в массовом сознании обретает силу исторического факта.

Параллельно советской и современной отечественной бурно развивалась и продолжает развиваться западная (в основном англо-американская) историография. Великобритания может считаться не только родиной железных дорог, но и местом возникновения культурно-исторически ориентированной истории транспорта, английские исследователи давно проявляют устойчивый интерес к истории женского труда на железных дорогах XIX - начала XX в. Первоначально учёные лишь косвенно обращались к данной проблематике в национальном масштабе $[70$, p. $62 ; 79$, p. 475-482; 68, p. 345$358 ; 71$, p. 92-93; 73, p. 134-135], заложив тем самым прочный фундамент для последующих гендерных исследований. В итоге, на сегодняшний день наиболее полные исследования по женскому труду на железных дорогах принадлежат перу британских историков Елены Войтчак (Helena Wojtczak), Дэвида Тернера (David Turner), Розы Мафесон (Rosa Matheson). Авторы посвятили свои работы женскому персоналу английских железных дорог в Викторианскую эпоху (1837-1901 гг.) [86; 85; 82; 83; 78]. Изданное в 2005 г. исследование Е. Войтчак «Railwaywomen» [87] стало первой работой, раскрывающей место железнодорожниц в истории железных дорог Великобритании. Недостаток сведений заставил английских исследователей признать, что изучать различные аспекты женской деятельности на железнодорожном транспорте значительно сложнее, чем мужской, особенно во времена, предшествующие Первой мировой войне [84].

Не меньший интерес к данной проблематике существует у французских [81, p. 999-1029; 75, p. 403-419] и у североамериканских историков [77, p. 214-217; 76]. В последние годы популярность обрела тема деятельности афроамериканских железнодорожниц на первых железных дорогах в США [74, p. 6-29; 69]. 
В работах зарубежных исследователей, посвящённых истории железных дорог Российской империи, небольшое внимание уделено женскому труду при строительстве магистрали между СанктПетербургом и Москвой [72, р. 393], а также накануне Первой русской революции 1905-1907 гг. [80, p. 42-43].

Таким образом, в историографии на сегодняшний день отсутствуют обобщающие систематизированные исследования по проблеме женского труда на железнодорожном транспорте Российской империи. Имеющиеся сведения не позволяют в достаточно полной мере воссоздать картину трудовых и бытовых аспектов жизнедеятельности женщин - служащих и рабочих железных дорог, их роли и вклада в развитие железнодорожной отрасли страны. Именно поэтому задача сделать железнодорожниц «видимыми» в историческом процессе, встроить в традиционную схему исторического повествования представляется чрезвычайно актуальной.

\section{СПИСОК ИСТОЧНИКОВ И ЛИТЕРАТУРЫ}

1. Августынюк А. И., Гвоздев М. Первая магистраль: [К 100-летию Октябрьской ж. д.]. Л., 1951. 600 с.

2. Амфитеатров А. В. Женщина в общественных движениях России. СПб., 1907. 56 с.

3. Барановский Л. С. Быт железнодорожных рабочих Белоруссии конца XIX — начала XX в.: дис. ... канд. ист. наук. Минск, 1977. $185 \mathrm{c}$.

4. Барановский Л. С. Медицинская помощь на железных дорогах Белоруссии в конце XIX — начале XX вв. // Здравоохранение Белоруссии. 1976. № 11. С. 49-53.

5. Белимов И. Т. К вопросу о численности и составе железнодорожного пролетариата Сибири накануне Октябрьской революции // Из истории рабочего класса Сибири. Новосибирск. 1964. С. 204-225.

6. Белинский Е. Ф. Формирование железнодорожного пролетариата на Украине во второй половине XIX века.: дис. ... канд. ист. наук. Киев, 1964. 254 с.

7. Большакова О. В. История России в гендерном измерении. Современная зарубежная историография: монография / О.В. Большакова; ред. 3.Ю. Метлицкая. М.: Институт научной информации по общественным наукам РАН, 2010. $122 \mathrm{c}$.

8. Бочанова Г. А. К вопросу о численности и составе служащих Сибирской железной дороги накануне Первой мировой войны // Бахрушинские чтения. 1971 г. Новосибирск, 1971. С. 102-113.

9. Вендрих А. А. фон. Записки эксплуатации железных дорог с военными целями: Курс. ст. кл. Николаев. инж. акад. СПб., $1886.628 \mathrm{c}$.

10. Верховской Н. П. Железнодорожная неразбериха: Terra incognita: Мысли практика по поводу беглых заметок «Не-техника». СПб.: Тип. А.С. Суворина, 1911. 231 с.

11. Внутреннее обозрение // Современник. 1863. № 5. С. 190-191.

12. Волгарь. 1913. 12 апр. С. 2.

13. Вопрос о службе женщин в железнодорожных обществах // Вестник Европы. 1874. Кн. 8. С. 792-807.

14. Вульфов А. Б. Повседневная жизнь российских железных дорог. М., 2007. 452 с.

15. Глинская A. А. Служба женщин на железной дороге // Труды 1-го Всероссийского женского съезда при Русском женском обществе в С.-Петербурге 10-16 декабря 1908 года. СПб., 1909. С. 400-404.

16. Гудков Б. И. Формирование и экономическое положение железнодорожников центральной части Европейской России в 1895-1914 гг.: дис. ... канд. ист. наук. Горький, 1984. 224 с.

17. Дворжеикий Н. М. Условия труда и быта транспортников на заре русских железных дорог. Л., 1925. 29 с.

18. Двоскина Л. Первый инженер в юбке, или как женщины завоевывали железную дорогу // Магистраль [Всеукраинская транспортная газета]. 2011. № 16-17. С. 6-7.

19. Делерт Д. Раскрепощение женского труда: сб. для изб-читален, клубов и женкружков / сост. Д. Делерт. М.; Л.: Гос. изд., 1926. 134 с.

20. Железнодорожницы: Лит. сборник [о жизни и труде лучших женщин-железнодорожниц]. М., 1940. 120 с.

21. Железнодорожный транспорт в 1913 г. (Стат. материалы) / под ред. В.В. Рачинского, В.Н. Соколова, Е.Н. Спенглера. М., 1925. 321 с.

22. Женский труд: [По поводу ст. в период. печати]. СПб., 1859. 87 с.

23. Зольников Д. М. Рабочее движение в Сибири в 1917 г. Новосибирск, 1969. 334 с.

24. Исторический обзор деятельности Комитета министров: К столетию Комитета министров (1802-1902). Т. 3: Комитет министров в царствование императора Александра Второго (1855 г. февраля $19-1881$ г. марта 1). СПб., 1903. Ч. 2.315 c.

25. Кефели Е. И. Опыт обследования быта женщин, работающих на Юго-Западных железных дорогах: (По данным проведенной в неделю «Матери пролетарки» анкеты) / [Соч.] сан. врача Е. И. Кефели. Б. м.: Б. и., [1923]. $8 \mathrm{c}$. 
26. Кечеджи-Шаповалов М. В. Женское движение в России и заграницей. СПб.: тип. Спб. о-ва печ. дела в России Е. Евдокимов, 1902. 210 с.

27. Ковалева И. Н. Женский вопрос в России в 50-60-х годах XIX в. // Проблемы истории русского общественного движения и исторической науки. М., 1981. С. 118-128.

28. Коллонтай А. М. Социальные основы женского вопроса. СПб.: Знание, 1909. 431 с.

29. Кунавина Г. С. Формирование железнодорожного пролетариата в Туркестане (1881-1914 гг.). Ташкент, 1967. $192 \mathrm{c}$.

30. Лилина 3. И. Солдаты тыла: (Женский труд во время и после войны). [Пг.]: Петрогр. сов. р. и к.-арм. д., 1918. $123 \mathrm{c}$.

31. Листок ответов и возражений // Современное слово. 1863. № 96. С. 80.

32. Мильман Э. М. Формирование кадров железнодорожного пролетариата Урала во второй половине XIX века // Из истории рабочего класса Урала: сб. ст. Пермь, 1961. С. 213-224.

33. Мирончук В. Д. Численность и состав рабочих Екатерининской железной дороги (1900-1914 гг.) // Рабочий класс Приднепровья. Формирование, традиции, социальный облик. Днепропетровск, 1989. С. $98-103$.

34. Мухин A. A. Формирование кадров пролетариата на Забайкальской железной дороге // Труды Иркутского гос. ун-та. Т. ХХХІ. Вып. 4. Иркутск, 1963. С. 3-14.

35. Награждение женщин-машинистов // Правда. Орган Центрального Комитета и МК ВКП(б). 1938.6 ноября. C. 3.

36. Необычайный юбилей // Железнодорожная жизнь на Дальнем Востоке. 1913. № 19. С. 8-9.

37. Новикова Н. В. Генерал Троицкая: [О первой в мире женщине-машинисте паровоза]. М.: Моск. рабочий, $1988.94 \mathrm{c}$.

38. О книге Н. П. Верховского «Железнодорожная неразбериха» // Железнодорожное дело. 1911. № 21-22. С. 35д-60д.

39. ОАО «РЖД». Отчет о деятельности в области устойчивого развития. 2017. $196 \mathrm{c.}$ URL: http://www.rzd.ru/dbmm/download?vp=1\&load=y\&col_id=121\&id=86890

40. Очерк сети русских железных дорог, их устройства, содержания и деятельности по 1892 год, составленный и изданный по поручению Русского отдела Постоянной комиссии Международных железнодорожных конгрессов VIII отделом Императорского русского технического общества. Т. 2. Отд. IV. Гл. І. СПб., 1896. Разд. паг.

41. Пажитнов K. А. Положение рабочего класса в России. Т. 3: Революционный период (с 1905 по 1923 г.). Л., 1924. $240 \mathrm{c}$.

42. Первая русская женщина на железнодорожной службе // Вестник Полесских железных дорог. 1913. № 13. C. $61-63$.

43. Первая русская женщина на железнодорожной службе // Семафор. 1913. № 16. С. 2.

44. Первая русская женщина на железнодорожной службе. 1863-1913. О.С. Кнушевицкая // Железнодорожная жизнь на Дальнем Востоке. 1913. № 19. С. 7-8.

45. Покровская М. И. Женщины на службе // Женский вестник. 1916. № 9. С. 120-123.

46. Пономарева В. В., Хорошилова Л. Б. Мир русской женщины: семья, профессия, домашний уклад. XVIII начало ХХ века. М., 2016. 279 с.

47. Правда. Орган Центрального Комитета и МК ВКП(б). 1938. 4 нояб.. С. 1.

48. Путилов А. Женский труд в почтово-телеграфном деле // Архив истории труда в России. Кн. 3. Пт., 1922. C. 91-95.

49. Пушкарева И. М., Пушкарева Н. Л. Женское участие в российской политической жизни начала XX в. (Советская и постсоветская историография) // Женщина в российском обществе. 2017. № 2. С. 15-34.

50. Рашин А. Г. Формирование рабочего класса России. Историко-экономические очерки. М., 1958. 623 с.

51. Рихтер И. И. Железнодорожная психология (материалы к стратегии и тактике железных дорог). СПб., 1896. $246 \mathrm{c.}$

52. Рихтер И. И. Личный состав русских железных дорог: (Патология, прогностика и терапия). СПб.: тип. Штаба отд. корп. жандармов, 1900. 236 с.

53. Сердюк B. A. Женский труд на железнодорожной службе: жизнь и деятельность билетного кассира О. С. Кнушевицкой (1863-1913 гг.) // Вестн. Оренбург. гос. пед. ун-та. Электронный научный журнал. 2019. № 1. С. 142-160.

54. Соломонова О. Время железных богинь // Гудок. 2017. 7 марта. Пол. 6.

55. Татаринова Н. И. Строительство коммунизма и труд женщин. М.: Экономика, 1964. 112 с.

56. Титок $B$. A. Формирование и революционная борьба железнодорожного пролетариата Белоруссии во второй половине XIX - начале XX вв.: дис. ... канд. ист. наук. Минск, 1966. 356 с.

57. Толковый словарь русского языка: в 4 т./ под ред. Д.Н. Ушакова. Т. 1.: А - Кюрины. М.: Гос. ин-т «Сов. энцикл.»; ОГИЗ, 1935. 1562 стб.

58. Тупик П. А. Железнодорожники Белоруссии в период империализма (численность, состав, положение): дис. ... канд. ист. наук. Минск, 1990. 251 с. 
59. Хобта А. В. Женщины на железнодорожном транспорте: от «интеллигентного» труда к профессиональному образованию // Вульфов А.Б. История железных дорог Российской империи: все-таки строить! М., 2016. C. 551-556.

60. Хобта А. В. Строительство Транссиба: очерки истории (конец XIX - начало XX вв.) / А.В. Хобта. Иркутск: Земля Иркутская, 2009. 382 с.

61. Цыплев В. Первая леди // Гудок. 2009. 22 окт. Пол. 7.

62. Чирков П. М. Решение женского вопроса в СССР (1917-1937 гг.). М.: Мысль, 1978. 255 с.

63. Чупров А. И. О положении служащих на железных дорогах (1876 год). Речи и статьи. Т. 3. М., 1909. С. $276-281$.

64. Шишков А. М. Эксплуатация железных дорог. Т. 1. СПб., 1877. 340 с.

65. Щеголев B. Н. Женщина-телеграфист в России и за границей / сост. В. Н. Щеголев, делопроизводитель Упр. гор. телеграфов в С.-Петербурге. СПб.: тип. т-ва «Обществ. Польза», 1894. 81 с.

66. Юкина И. И. История женщин России: Женское движение и феминизм в 1850-1920-е годы: Материалы к библиогр. СПб., 2003. 232 с.

67. Яковлев Я. А. Рассказы о Томском железнодорожном техникуме. Т. 1. Томск, 2002. 305 с.

68. Bagwell P. S. The railwaymen. The history of the National Union of Railwaymen. London: George Allen and Unwin LTD, 1963. 725 p.

69. Blouin L. A., Sutton K. Looking Back: Women in Railroading. URL: http://www.nrrhof.org/single-post/2018/03/ 08/Looking-Back-Women-in-Railroading

70. Cole G. D. H., Arnot P. R. Trade Unionism on the railways. Its history and problems. London: George Allen and Unwin LTD. 1917. $147 \mathrm{p}$.

71. Greenwald M. W. Women, war, and work. The Impact of World War I on Women Workers in the United States. London: Cornell University, 1980. 352 p.

72. Haywood R. M. Russia Enters Railway Age, 1842-1855. Boulder, CO: East European Monographs, 1998.635 p.

73. Hylton S. What the Railways Did for Us. Publisher: Amberley Publishing. 2015. 240 p.

74. Kornweibel T. «Not at all proper for women»: black female railroaders // Railroad History. 2009. № 201. P. 6-29.

75. Lamoureux D. Des cheminotes en usine: des femmes aux ateliers d'Arles (1914-1920) // Revue d'histoire des chemins de fer. 2003. № 28-29. P. 403-419.

76. Levinson N. S. She's been working on the railroad. New York: Lodestar/Dutton, 1997. 104 p.

77. Licht W. Working for the Railroad: The Organization of Work in the Nineteenth Century. New Jersey: Princeton University Press, 1983. 352 p.

78. Matheson R. The fair sex: women and the Great Western Railway. Chalford: Tempus, 2011. $160 \mathrm{p}$.

79. Pratt E. A. British railways and the Great War; organisation, efforts, difficulties and achievements. Publisher London: Selwyn and Blount. 1921. 1192 p.

80. Reichman H. Railwaymen and revolution: Russia, 1905 / Henry Reichman. Berkeley etc.: Univ. of California press, 1987. $351 \mathrm{p}$.

81. Ribeill $G$. Gestion et organisation du travail dans les compagnies de chemins de fer, des origines a 1860 // Annales. Histoire, Sciences Sociales. 1987. № 5. P. 999-1029.

82. Turner D. Discovering Britain's first Railwaywomen (1840s and 1850s) - Part 1. URL: http://turniprail.blogspot.de/ 2011/09/discovering-britains-first-railwaywomen.html

83. Turner D. Discovering Britain's first Railwaywomen (1840s and 1850s) - Part 2. URL: http://turniprail.blogspot.de/ 2011/10/turnip-rail-discovering-britains-first.html

84. Turner D. The Female L\&SWR Clerk - Part 1. URL: http://turniprail.blogspot.ru/2010/03/female-1-clerk-part-1.html

85. Turner D. The Female L\&SWR Clerk - Part 2. URL: http://turniprail.blogspot.de/2010/03/female-1-clerk-part-2.html

86. Turner D. Uncovering the Hidden History of Britain's Railwaywomen. URL: http://turniprail.blogspot.ru/2010/09/ uncovering-hidden-history-of-britains.html

87. Wojtczak H. Railwaywomen: Exploitation, Betrayal, and Triumph in the Workplace. Hastings: Hastings Press, 2005. $375 \mathrm{p}$.

Сердюк Владимир Александрович,

кандидат исторических наук, доцент кафедры истории, философии и культурологии

ФГБОУ ВО «Омский государственный университет путей сообщения»

644046, Россия, г. Омск, пр. Маркса, 35

E-mail: a.serdyuk@mail.ru 


\title{
V.A. Serdiuk
}

\section{FEMALE LABOR ON THE RAILWAYS OF THE RUSSIAN EMPIRE: HISTORIOGRAPHIC REVIEW}

\author{
DOI: $10.35634 / 2412-9534-2021-31-1-22-33$
}

The article is devoted to a general historiographic review of domestic and foreign literature on the study of the problem of the use of female labor on railways. The subject of the research is the publications of pre-revolutionary, soviet and modern researchers on the issue of women's contribution to the development of the railway industry of the Russian empire in the XIX - early XX centuries. The author attempts to answer the question how the place and role of women in railway activities before 1917 in the pre-revolutionary and soviet periods, as well as after the collapse of the USSR, was assessed. The article concluded that the literature of the post-soviet period significantly expanded the scope of studying the problem, but still relies on the historiography of the soviet period.

Keywords: historiography, woman, female labor, railways, railway service, Russian empire.

\section{REFERENCES}

1. Avgustynjuk A. I., Gvozdev M. Pervaja magistral': [K 100-letiju Oktjabr'skoj zh. d.] [The first line: [To the 100th anniversary of the October Railway]]. Leningrad, 1951, 600 p. (In Russian).

2. Amfiteatrov A. V. Zhenshhina v obshhestvennyh dvizhenijah Rossii [Woman in public movements of Russia]. St. Petersburg, 1907, 56 p. (In Russian).

3. Baranovskij L. S. Byt zheleznodorozhnyh rabochih Belorussii konca XIX — nachala XX v. [Life of railway workers in Belarus at the end of the XIX - beginning of the XX centuries]. Dis. ... kand. ist. nauk, Minsk, 1977, 185 p. (In Russian).

4. Baranovskij L. S. Medicinskaja pomoshh' na zheleznyh dorogah Belorussii v konce XIX — nachale XX vv. [Medical assistance on the railways of Belarus in the late XIX - early XX centuries]. Zdravoohranenie Belorussii [Healthcare of Belarus], 1976. no. 11, pp. 49-53. (In Russian).

5. Belimov I. T. K voprosu o chislennosti i sostave zheleznodorozhnogo proletariata Sibiri nakanune Oktjabr'skoj revoljucii [On the issue of the size and composition of the railway proletariat of Siberia on the eve of the October Revolution]. Iz istorii rabochego klassa Sibiri [From the history of the working class of Siberia], Novosibirsk, 1964, pp. 204-225. (In Russian).

6. Belinskij E. F. Formirovanie zheleznodorozhnogo proletariata na Ukraine vo vtoroj polovine XIX veka [Formation of the railway proletariat in Ukraine in the second half of the XIX century]. Dis. ... kand. ist. nauk, Kiev, 1964, 254 p. (In Russian).

7. Bol'shakova O. V. Istorija Rossii v gendernom izmerenii. Sovremennaja zarubezhnaja istoriografija [History of Russia in the gender dimension. Modern foreign historiography]: monografija. Moscow, Ed. of the Institute for Scientific Information on Social Sciences of the RAS, 2010, 122 p. (In Russian).

8. Bochanova G. A. K voprosu o chislennosti i sostave sluzhashhih Sibirskoj zheleznoj dorogi nakanune Pervoj mirovoj vojny [On the issue of the number and composition of employees of the Siberian Railway on the eve of the First World War]. Bahrushinskie chtenija, Novosibirsk, 1971, pp. 102-113. (In Russian).

9. Vendrih A. A fon. Zapiski jekspluatacii zheleznyh dorog s voennymi celjami [Notes of the operation of railways for military purposes]: Kurs. st. kl. Nikolaev. inzh. akad., St. Petersburg, 1886, 628 p. (In Russian).

10. Verhovskoj N. P. Zheleznodorozhnaja nerazberiha: Terra incognita [Railroad mess: Terra incognita]: Mysli praktika po povodu beglyh zametok "Ne-tehnika" / N.P. Verhovskoj. St. Petersburg, tip. A.S. Suvorina, 1911, 231 p. (In Russian).

11. Vnutrennee obozrenie [Internal Review]. Sovremennik [Contemporary], 1863, no. V, pp. 190-191. (In Russian).

12. Volgar' [Volgar], 1913, april 12, p. 2. (In Russian).

13. Vopros o sluzhbe zhenshhin v zheleznodorozhnyh obshhestvah [Question about the service of women in railway societies]. Vestnik Evropy [Bulletin of Europe], 1874, B. 8, pp. 792-807. (In Russian).

14. Vul'fov A. B. Povsednevnaja zhizn' rossijskih zheleznyh dorog [The Daily Life of Russian Railways]. Moscow, 2007, 452 p. (In Russian).

15. Glinskaja A. A. Sluzhba zhenshhin na zheleznoj doroge [Service of women on the railway]. Trudy 1-go Vserossijskogo zhenskogo sezda pri Russkom zhenskom obshhestve v S.-Peterburge 10-16 dekabrja 1908 goda [Proceedings of the 1st All-Russian Women's Congress at the Russian Women's Society in St. Petersburg, December 10-16, 1908], St. Petersburg, 1909, pp. 400-404. (In Russian).

16. Gudkov B. I. Formirovanie i jekonomicheskoe polozhenie zheleznodorozhnikov central'noj chasti Evropejskoj Rossii v 1895-1914 gg. [The Formation and Economic Situation of the Railway Workers of the Central Part of European Russia in 1895-1914]. Dis. ... kand. ist. nauk, Gorky, 1984, 224 p. (In Russian).

17. Dvorzheckij N. M. Uslovija truda i byta transportnikov na zare russkih zheleznyh dorog [Working and living conditions of transport workers at the dawn of Russian railways]. Leningrad, 1925, 29 p. (In Russian). 
18. Dvoskina L. Pervyj inzhener v jubke, ili kak zhenshhiny zavoevyvali zheleznuju dorogu [The first engineer in a skirt, or how women conquered the railway]. Magistral' [Vseukrainskaja transportnaja gazeta] [Magistral [AllUkrainian Transport Newspaper]], 2011, no. 16-17, pp. 6-7. (In Russian).

19. Delert $D$. Raskreposhhenie zhenskogo truda [The emancipation of female labor]: Sb. dlja izb-chitalen, klubov i zhenkruzhkov / sost. D. Delert. Moscow; Leningrad, "Gos. izd.” Publ., 1926, 134 p. (In Russian).

20. Zheleznodorozhnicy: Lit. sbornik [o zhizni i trude luchshih zhenshhin-zheleznodorozhnic] [Railway: Lit. collection [about the life and work of the best women railway workers]]. Moscow, 1940, 120 p. (In Russian).

21. Zheleznodorozhnyj transport v 1913 g. (Stat. materialy) [Railway Transport in 1913 (Statistical Materials)] / pod red. V.V. Rachinskogo, V.N. Sokolova, E.N. Spenglera. Moscow, 1925, 321 p. (In Russian).

22. Zhenskij trud: [Po povodu st. v period. pechati] [Female labor: [Regarding articles in the periodical press]]. St. Petersburg, 1859, 87 p. (In Russian).

23. Zol'nikov D. M. Rabochee dvizhenie v Sibiri v 1917 g. [Labor movement in Siberia in 1917]. Novosibirsk, 1969, 334 p. (In Russian).

24. Istoricheskij obzor dejatel'nosti Komiteta ministrov [Historical review of the activities of the Committee of Ministers]: K stoletiju Komiteta ministrov (1802-1902), Vol. 3: Komitet ministrov v carstvovanie imperatora Aleksandra Vtorogo (1855 g. fevralja 19-1881 g. marta 1). St. Petersburg, 1903, Ch. 2, 315 p. (In Russian).

25. Kefeli E. I. Opyt obsledovanija byta zhenshhin, rabotajushhih na Jugo-Zapadnyh zheleznyh dorogah [Experience in the survey of the life of women working on the South-Western railways]: (Po dannym proved. v nedelju «Materi proletarki» ankety) / [Soch.] san. vracha E. I. Kefeli. B. m.: B. i., [1923], 8 p. (In Russian).

26. Kechedzhi-Shapovalov M. V. Zhenskoe dvizhenie v Rossii i zagranicej [Women's movement in Russia and abroad] / M.V. Kechedzhi-Shapovalov. St. Petersburg, tip. Spb. o-va pech. dela v Rossii E. Evdokimov, 1902, 210 p. (In Russian).

27. Kovaleva I. N. Zhenskij vopros v Rossii v 50-60-h godah XIX v. [The women's issue in Russia in the 50s $-60 \mathrm{~s}$ of the XIX century]. Problemy istorii russkogo obshhestvennogo dvizhenija i istoricheskoj nauki [Problems of the history of the Russian social movement and historical science]. Moscow, 1981, pp. 118-128. (In Russian).

28. Kollontaj A. M. Social'nye osnovy zhenskogo voprosa [Social foundations of the female question] / A. M. Kollontaj. St. Petersburg, "Znanie” Publ., 1909, 431 p. (In Russian).

29. Kunavina G. S. Formirovanie zheleznodorozhnogo proletariata v Turkestane (1881-1914 gg.) [Formation of the railway proletariat in Turkestan (1881-1914)]. Tashkent, 1967, 192 p. (In Russian).

30. Lilina Z. I. Soldaty tyla: (Zhenskij trud vo vremja i posle vojny) [Soldiers of the rear: (Female labor during and after the war)] / Z. Lilina. Petrograd, Petrogr. sov. r. i k.-arm. d., 1918, 123 p. (In Russian).

31. Listok otvetov i vozrazhenij [Leaf answers and objections]. Sovremennoe slovo [Modern word], 1863, no. 96, p. 80. (In Russian).

32. Mil'man Je. M. Formirovanie kadrov zheleznodorozhnogo proletariata Urala vo vtoroj polovine XIX veka [Formation of personnel of the railway proletariat of the Urals in the second half of the XIX century]. Iz istorii rabochego klassa Urala [From the history of the working class of the Urals]. Sb. st. Perm, 1961, pp. 213-224. (In Russian).

33. Mironchuk V. D. Chislennost' i sostav rabochih Ekaterininskoj zheleznoj dorogi (1900-1914 gg.) [The number and composition of workers Ekaterininskaya railway (1900-1914)]. Rabochij klass Pridneprov'ja. Formirovanie, tradicii, social'nyj oblik [Working class Dnieper. Formation, tradition, social appearance]. Dnepropetrovsk, 1989, pp. 98103. (In Russian).

34. Muhin A. A. Formirovanie kadrov proletariata na Zabajkal'skoj zheleznoj doroge [Forming the cadres of the proletariat on the Trans-Baikal Railway]. Trudy Irkutskogo gos. un-ta [Works of the Irkutsk State University], vol. XXXI, rel. 4, Irkutsk, 1963, pp. 3-14. (In Russian).

35. Nagrazhdenie zhenshhin-mashinistov [Rewarding women machinists]. Pravda [True]. Organ Central'nogo Komiteta i MK VKP(b), 1938, november 6, p. 3. (In Russian).

36. Neobychajnyj jubilej [Unusual anniversary]. Zheleznodorozhnaja zhizn' na Dal'nem Vostoke [Railway life in the Far East], 1913, no. 19, pp. 8-9. (In Russian).

37. Novikova $N$. $V$. General Troickaja: [O pervoj v mire zhenshhine - mashiniste parovoza] [General Troitskaya: [About the world's first female engine driver]]. Moscow, "Mosk. Rabochij” Publ., 1988, 94 p. (In Russian).

38. O knige N. P. Verhovskogo "Zheleznodorozhnaja nerazberiha" [About the book N. P. Verkhovsky "Railroad mess"]. Zheleznodorozhnoe delo [Railway business], 1911, no. 21-22, pp. 35d-60d. (In Russian).

39. OAO "RZhD". Otchet o dejatel'nosti v oblasti ustojchivogo razvitija [Russian Railways. Sustainability Report]. 2017, 196 p. URL: http://www.rzd.ru/dbmm/download?vp=1\&load=y\&col_id=121\&id=86890 (In Russian).

40. Ocherk seti russkih zheleznyh dorog, ih ustrojstva, soderzhanija i dejatel'nosti po 1892 god [Essay on the network of Russian railways, their design, content and activities for 1892], sostavlennyj i izdannyj po porucheniju Russkogo otdela Postojannoj komissii Mezhdunarodnyh zheleznodorozhnyh kongressov VIII-m otdelom Imperatorskogo russkogo tehnicheskogo obshhestva, vol. 2, otd. IV, Gl. I. St. Petersburg, 1896, razd. pag. (In Russian).

41. Pazhitnov K. A. Polozhenie rabochego klassa v Rossii [The situation of the working class in Russia], vol. 3, Revoljucionnyj period (s 1905 po 1923 g.). Leningrad, 1924, 240 p. (In Russian). 
42. Pervaja russkaja zhenshhina na zheleznodorozhnoj sluzhbe [The first Russian woman in the railway service]. Vestnik Polesskih zheleznyh dorog [Bulletin of the Poles'e Railways], 1913, no. 13, pp. 61-63. (In Russian).

43. Pervaja russkaja zhenshhina na zheleznodorozhnoj sluzhbe [The first Russian woman in the railway service] // Semafor [Semaphore], 1913, no. 16, p. 2. (In Russian).

44. Pervaja russkaja zhenshhina na zheleznodorozhnoj sluzhbe. 1863-1913. O.S. Knushevickaja [The first Russian woman in the railway service. 1863-1913. O.S. Knushevitskaya]. Zheleznodorozhnaja zhizn' na Dal'nem Vostoke [Railway life in the Far East], 1913, no. 19, pp. 7-8. (In Russian).

45. Pokrovskaja M. I. Zhenshhiny na sluzhbe [Women in the service]. Zhenskij vestnik [Women's Bulletin], 1916, no. 9, pp. 120-123. (In Russian).

46. Ponomareva V. V., Horoshilova L. B. Mir russkoj zhenshhiny: sem'ja, professija, domashnij uklad. XVIII - nachalo XX veka [The World of a Russian Woman: Family, Profession, Home Style. XVIII - early XX century]. Moscow, 2016, 279 p. (In Russian).

47. Pravda [True]. Organ Central'nogo Komiteta i MK VKP(b), 1938, nov. 4, p. 1. (In Russian).

48. Putilov A. Zhenskij trud v pochtovo-telegrafnom dele [Female labor in postal and telegraph business]. Arhiv istorii truda v Rossii [Archive of Labor History in Russia]. B. 3, Petrograd, 1922, pp. 91-95. (In Russian).

49. Pushkareva I. M., Pushkareva N. L. Zhenskoe uchastie v rossijskoj politicheskoj zhizni nachala XX v. (Sovetskaja i postsovetskaja istoriografija) [Female participation in Russian political life at the beginning of the 20th century. (Soviet and Post-Soviet Historiography)]. Zhenshhina v rossijskom obshhestve [Woman in Russian Society], 2017, no. 2, pp. 15-34. (In Russian).

50. Rashin A. G. Formirovanie rabochego klassa Rossii. Istoriko-jekonomicheskie ocherki [Formation of the working class of Russia. Historical and economic essays]. Moscow, 1958, 623 p. (In Russian).

51. Rikhter I. I. Zheleznodorozhnaja psihologija (materialy k strategii i taktike zheleznyh dorog) [Zheleznodorozhnaya psychology (materials for the strategy and tactics of railways)]. St. Petersburg, 1896, 246 p. (In Russian).

52. Rikhter I. I. Lichnyj sostav russkih zheleznyh dorog: (Patologija, prognostika i terapija) [The personnel of the Russian railways: (Pathology, prognostics and therapy)]. St. Petersburg, "Tip. Shtaba otd. korp. Zhandarmov" Publ., 1900, 236 p. (In Russian).

53. Serdiuk $V$. A. Zhenskij trud na zheleznodorozhnoj sluzhbe: zhizn' i dejatel'nost' biletnogo kassira O. S. Knushevickoj (1863-1913 gg.) [Female labor in the railway service: the life and activity of the ticket teller O. S. Knushevitskaya (1863-1913)]. Vestnik Orenburgskogo gosudarstvennogo pedagogicheskogo universiteta [Bulletin of the Orenburg State Pedagogical University]. Jelektronnyj nauchnyj zhurnal, 2019, no. 1, pp. 142-160. (In Russian).

54. Solomonova $O$. Vremja zheleznyh bogin' [Time of iron goddesses], Gudok [Hooter], 2017, march 7, st. 6. (In Russian).

55. Tatarinova N. I. Stroitel'stvo kommunizma i trud zhenshhin [The construction of communism and the labor of women]. Moscow, “Jekonomika” Publ., 1964, 112 p. (In Russian).

56. Titok $V$. A. Formirovanie i revoljucionnaja bor'ba zheleznodorozhnogo proletariata Belorussii vo vtoroj polovine XIX - nachale XX vv. [The formation and revolutionary struggle of the railway proletariat of Belarus in the second half of the XIX - early XX centuries], Dis. ... kand. ist. nauk. Minsk, 1966, 356 p. (In Russian).

57. Tolkovyj slovar' russkogo jazyka [Dictionary of the Russian language]: v 4 b. / pod red. D.N. Ushakova, vol. 1.: A Kjuriny. Moscow, Gos. in-t "Sov. jencikl.”; OGIZ Publ., 1935, 1562 stb. (In Russian).

58. Tupik P. A. Zheleznodorozhniki Belorussii v period imperializma (chislennost', sostav, polozhenie) [Railway workers of Belarus in the period of imperialism (size, composition, position)], Dis. ... kand. ist. nauk. Minsk, 1990, 251 p. (In Russian).

59. Hobta A. $V$. Zhenshhiny na zheleznodorozhnom transporte: ot “intelligentnogo" truda k professional'nomu obrazovaniju [Women in rail transport: from “intelligent” labor to vocational education]. Vul'fov A. B. Istorija zheleznyh dorog Rossijskoj imperii: vse-taki stroit'! [The history of the railways of the Russian Empire: still build]. Moscow, 2016, pp. 551-556. (In Russian).

60. Hobta A. V. Stroitel'stvo Transsiba: ocherki istorii (konec XIX - nachalo XX vv.) [Transsib Construction: Essays on History (late XIX - early XX centuries)]. Irkutsk, “Zemlja Irkutskaja” Publ., 2009, 382 p. (In Russian).

61. Cyplev V. Pervaja ledi [First Lady]. Gudok [Hooter], 2009, october 22, st. 7. (In Russian).

62. Chirkov P. M. Reshenie zhenskogo voprosa v SSSR (1917-1937 gg.) [Solution of the women's question in the USSR (1917-1937)]. Moscow, "Mysl” Publ., 1978, 255 p. (In Russian).

63. Chuprov A. I. O polozhenii sluzhashhih na zheleznyh dorogah (1876 god) [On the position of employees on railways (1876)]. A. I. Chuprov, Rechi i stat'I [Speeches and articles], vol. 3. Moscow, 1909, pp. 276-281. (In Russian).

64. Shishkov A. M. Jekspluatacija zheleznyh dorog [Operation of railways], vol. 1. St. Petersburg, 1877, 340 p. (In Russian).

65. Shhegolev $V$. . Z. Zhenshhina-telegrafist v Rossii i za granicej [A woman telegraphist in Russia and abroad]. Sost. V. N. Shhegolev, deloproizvoditel' Upr. gor. telegrafov v S.-Peterburge. St. Petersburg, "Obshhestv. Pol'za” Publ., 1894, 81 p. (In Russian). 
66. Jukina I. I. Istorija zhenshhin Rossii: Zhenskoe dvizhenie i feminizm v 1850-1920-e gody [The history of women in Russia: The women's movement and feminism in the 1850-1920s]: Materialy k bibliogr. St. Petersburg, 2003,232 p. (In Russian).

67. Jakovlev Ja. A. Rasskazy o Tomskom zheleznodorozhnom tehnikume [Stories about the Tomsk Railway College], vol. 1. Tomsk, 2002, 305 p. (In Russian).

68. Bagwell P. S. The railwaymen. The history of the National Union of Railwaymen. London, George Allen and Unwin LTD, 1963, 725 p. (in English).

69. Blouin L. A., Sutton K. Looking Back: Women in Railroading. URL: http://www.nrrhof.org/single-post/2018/03/08/ Looking-Back-Women-in-Railroading (in English).

70. Cole G. D. H., Arnot P. R. Trade Unionism on the railways. Its history and problems. London, George Allen and Unwin LTD, 1917, 147 p. (in English).

71. Greenwald M. W. Women, war, and work. The Impact of World War I on Women Workers in the United States. London, Cornell University, 1980, 352 p. (in English).

72. Haywood R. M. Russia Enters Railway Age, 1842-1855. Boulder, CO, East European Monographs, 1998, 635 p. (in English).

73. Hylton S. What the Railways Did for Us. The Hill, Amberley Publ., 2015. 240 p. (in English).

74. Kornweibel T. «Not at all proper for women»: black female railroaders. Railroad History, 2009, no. 201 , pp. 6-29. (in English).

75. Lamoureux D. Des cheminotes en usine: des femmes aux ateliers d'Arles (1914-1920). Revue d'histoire des chemins de fer, 2003, no. 28-29, pp. 403-419. (in French).

76. Levinson N. S. She's been working on the railroad. New York, Lodestar/Dutton, 1997, 104 p. (in English).

77. Licht $W$. Working for the Railroad: The Organization of Work in the Nineteenth Century. New Jersey, Princeton University Press, 1983, 352 p. (in English).

78. Matheson R. The fair sex: women and the Great Western Railway. Chalford, Tempus, 2011, 160 p. (in English).

79. Pratt E. A. British railways and the Great War; organisation, efforts, difficulties and achievements. London, Selwyn and Blount, 1921, 1192 p. (in English).

80. Reichman H. Railwaymen and revolution: Russia, 1905 / Henry Reichman. Berkeley etc., Univ. of California press, 1987, 351 p. (in English).

81. Ribeill $G$. Gestion et organisation du travail dans les compagnies de chemins de fer, des origines a 1860 . Annales. Histoire, Sciences Sociales, 1987, no. 5, pp. 999-1029. (in English).

82. Turner D. Discovering Britain's first Railwaywomen (1840s and 1850s) - Part 1. URL: http://turniprail.blogspot.de/ 2011/09/discovering-britains-first-railwaywomen.html (in English).

83. Turner D. Discovering Britain's first Railwaywomen (1840s and 1850s) - Part 2. URL: http://turniprail.blogspot.de/ 2011/10/turnip-rail-discovering-britains-first.html (in English).

84. Turner D. The Female L\&SWR Clerk - Part 1. URL: http://turniprail.blogspot.ru/2010/03/female-1-clerk-part-1.html (in English).

85. Turner D. The Female L\&SWR Clerk - Part 2. URL: http://turniprail.blogspot.de/2010/03/female-l-clerk-part-2.html (in English).

86. Turner D. Uncovering the Hidden History of Britain's Railwaywomen. URL: http://turniprail.blogspot.ru/2010/09/ uncovering-hidden-history-of-britains.html (in English).

87. Wojtczak H. Railwaywomen: Exploitation, Betrayal, and Triumph in the Workplace. Hastings, Hastings Press, 2005, 375 p. (in English).

Serdiuk V.A., Candidate of History, Associate Professor at Department of History, Philosophy and Cultural Studies Omsk State Transport University

Marksa pr., 35, Omsk, Russia, 644046

E-mail: a.serdyuk@mail.ru 